\title{
Neuronal Acetylcholine Receptor Subunit Alpha-3
}

National Cancer Institute

\section{Source}

National Cancer Institute. Neuronal Acetylcholine Receptor Subunit Alpha-3. NCI

Thesaurus. Code C77125.

Neuronal acetylcholine receptor subunit alpha-3 (503 aa, $\sim 57 \mathrm{kDa}$ ) is encoded by the human CHRNA3 gene. This protein plays a role in ion transport. 